\title{
Increased islet neogenesis without increased islet mass precedes autoimmune attack in diabetes-prone rats
}

\author{
Lisa M Kauri ${ }^{1, *}$, Gen-Sheng Wang ${ }^{1, *}$, Christopher Patrick ${ }^{1,2}$, Mirella Bareggi ${ }^{1,2}$, David J Hill ${ }^{3}$ and Fraser W Scott ${ }^{1,2,4}$
}

We reported previously that young BioBreeding diabetes-prone (BBdp) rats display increased neogenic extra-islet insulin ${ }^{+}$clusters (EICs, $<4$ insulin ${ }^{+}$cells) without an increase in $\beta$-cell mass. Therefore, we investigated the possibility that abnormal islet expansion occurs in BBdp rats before the appearance of islet inflammation. Islet expansion was analyzed in pancreata from 14 to 45 day BBdp and control (BioBreeding control, BBC) rats using immunohistochemistry, morphometry, laser capture microdissection and reverse transcriptase-PCR. mRNA expression for Neurogenin-3, a developmental marker of endocrine progenitors, was three-fold greater in EIC of weanling BBdp and BBC rats compared with islet cells. With increasing age (14-30 days), Neurogenin-3 expression decreased in EIC and increased in islets. In $\mathrm{BBdp}$ rats, EIC number and $\beta$-cell proliferation within EIC was greater compared with $\mathrm{BBC}$ animals; apoptosis did not differ. The area of small and medium islets in BBdp rats was greater than BBc rats between 14 and 30 days, but this did not result in increased total islet area or $\beta$-cell mass. In addition, the number and area of very large islets was low at 45 days. The frequency of proliferating $\beta$-cells decreased with increasing islet size in BBdp but was constant in BBc rats. Cell cycle analysis of islets revealed more G1 cells and fewer G2 cells in BBdp rats. The ratio of cyclinD2/Cdkn1a, genes that respectively promote or inhibit cell cycle progression, was decreased in BBdp islets. These results suggest that despite increased islet neogenesis, the capacity for islet expansion in diabetes-prone rats is compromised possibly due to decreased proliferative capacity with increasing islet size associated with a partial block at the G1/S cell cycle boundary in islet cells.

Laboratory Investigation (2007) 87, 1240-1251; doi:10.1038/labinvest.3700687; published online 1 October 2007

KEYWORDS: diabetes; $\beta$-cell; islet neogenesis; cell cycle; apoptosis; BioBreeding rat

The development of type 1 diabetes is the result of a dysfunction in the immune system associated with $\beta$-cell destruction. It is generally thought that hyperglycemia occurs when an inflammatory process destroys $80-90 \%$ of the $\beta$-cells and regenerative processes fail to maintain $\beta$-cell mass above a critical threshold. ${ }^{1}$ Presumably, if one had a large enough islet mass or had sufficient capacity for $\beta$-cell regeneration, one would remain asymptomatic despite an ongoing autoimmune attack. We previously observed increased islet neogenesis in 45-day-old BioBreeding diabetesprone (BBdp) rats without a significant increase in islet mass compared with BioBreeding control (BBc) rats, ${ }^{2}$ but the basis of this difference was unclear.

Pancreatic $\beta$-cells comprise a dynamic cell population capable of continually responding to various physiological challenges.
$\beta$-Cell mass can be modified through changes in neogenesis, replication, cell volume and apoptosis. ${ }^{3}$ In the embryonic pancreas, endocrine cells bud from the ductal epithelium ${ }^{4}$ and form extra-islet insulin ${ }^{+}$cell clusters (EICs; $<4$ insulin $^{+}$cells), which subsequently expand into larger islets. ${ }^{5}$ At birth, the pancreas is not fully mature and continues developing throughout the perinatal period, reaching adult size and morphology following weaning. ${ }^{6,7}$ Post-weaning, the number of islets and total islet volume increases with age but the average islet size remains constant, indicating the formation of new islets. ${ }^{8}$ The presence of EIC has been used as an indicator of islet neogenesis, with the number of EIC increasing in response to greater insulin demand or islet injury. ${ }^{9-11}$ EICs are believed to originate from extra-islet progenitor cells or from duct cells $s^{3,12}$ that initiate the process of islet neogenesis.

\footnotetext{
${ }^{1}$ Chronic Disease and Molecular Medicine Programs, Ottawa Health Research Institute, Ottawa, ON, Canada; ${ }^{2}$ Department of Biochemistry, Microbiology and Immunology, University of Ottawa, Ottawa, ON, Canada; ${ }^{3}$ Lawson Health Research Institute, London, ON, Canada and ${ }^{4}$ Department of Medicine, University of Ottawa, Ottawa, ON, Canada

Correspondence: Dr FW Scott, PhD, Chronic Disease and Molecular Medicine Programs, Ottawa Health Research Institute, Lab N1/Box 221, The Ottawa HospitalGeneral Campus, 501 Smyth Road, Ottawa, ON, Canada K1H 8L6. E-mail: fscott@ohri.ca

*These authors contributed equally to this work.

Received 16 July 2007; revised 28 August 2007; accepted 4 September 2007
} 
There are some indications that islet defects are present in young diabetes-prone animals. ${ }^{2,8}$ For example, nonobese diabetic (NOD) mice and BBdp rats exhibit subtle abnormalities in the target tissue, including increased islet neogenesis, ${ }^{2,13}$ increased apoptosis, ${ }^{14}$ decreased clearance of apoptotic bodies, ${ }^{15}$ abnormal islet morphology ${ }^{16}$ and increased aggregation of cellular prion protein in $\beta$-cells. ${ }^{17}$ Most of these studies focused on islet abnormalities as potential initiators of the $\beta$-cell specific autoimmune attack. A key question remains whether islet development per se is abnormal in diabetes-prone individuals.

NOD mice display a peri-islet immune cell accumulation at weaning followed by development of a pronounced islet infiltration by mononuclear cells, a process called insulitis. In BBdp rats, insulitis develops 4 weeks after weaning with a similar appearance to the patchy insulitis seen in human patients. ${ }^{18}$ The severity of islet infiltration has been reported to correlate with $\beta$-cell dysfunction and impaired glucose tolerance. ${ }^{19}$ Therefore, to investigate the capacity for islet expansion without the confounding effect of a coincident immune cell infiltrate in the pancreas, we performed detailed analyses of the natural course of islet maturation in young $\mathrm{BBdp}$ and $\mathrm{BBC}$ rats. If islet development was impaired early in life, $\beta$-cell reserves and the regenerative capacity of $\beta$-cells would be insufficient to withstand an autoimmune attack and maintain normal blood glucose. We hypothesized that islet expansion could be impaired in BBdp rats due to innate target tissue abnormalities. To investigate potential defects in islet development before the $\beta$-cell-specific autoimmune attack is established, we studied islet neogenesis, development, proliferation and apoptosis in $14-45$ day pre-insulitic BB rats.

\section{MATERIALS AND METHODS \\ Animals}

Specific pathogen-free BBdp and BBC rats were purchased from the Animal Resources Division of Health Canada (Ottawa, ON, Canada). Animals were weaned at 23 days onto a standard cereal-based diet (Ziegler Brothers, Gardners, PA, USA) and permitted free access to water. To maximize labeling of $\beta$-cells undergoing proliferation, rats were injected intraperitoneally with $50 \mathrm{mg}$ of 5-bromo-2-deoxyuridine (BrdU) (Sigma, St Louis, MO, USA) per kg body weight, twice daily for 3 days beginning at 28 days of age and killed $2 \mathrm{~h}$ following the final injection. Animals were anesthetized with 3\% isoflurane in oxygen and killed by exsanguination. Pancreata were weighed and either immersed in liquid nitrogen and maintained at $-80^{\circ} \mathrm{C}$ for laser capture microdissection (LCM) or immersed in Bouin's fixative or Universal Molecular Fixative solution (Sakura Finetek, Torrance, CA, USA) and embedded in paraffin for immunohistochemistry. This study was approved by the Local Ethics Committees and the animals were maintained in accordance with the laboratory animal guidelines of the Canadian Council on Animal Care.

\section{Immunohistochemistry}

Reagents for immunohistochemistry were obtained from DAKO Cytomation (Mississauga, ON, Canada). Sections of $5 \mu \mathrm{m}$ thickness were deparaffinized, rehydrated and primary antibody was applied followed by a biotin-conjugated secondary antibody for conventional immunohistochemistry. Tissue sections were incubated with avidin-biotin-peroxidase complex and a dark-brown color was developed using 3,3-diaminobenzidine and hydrogen peroxide. For double staining, a second primary antibody was applied, followed by alkaline phosphatase-conjugated secondary antibody. A purple-blue color was developed using 5-bromo,4-chloro, 3-indolylphosphate/nitroblue tetrazolium as described previously. ${ }^{20}$

\section{Islet Area, Insulin ${ }^{+}$Area, $\boldsymbol{\beta}$-Cell Mass and EIC Number} Insulin-stained sections were scanned at $\times 100$ using a Zeiss Axioplan2 microscope equipped with a digital CCD color camera (QImaging, Burnaby, BC, Canada). Around 120 images were generated from each section. Interstitial tissue (ie fat, lymphoid tissue) in each image was manually traced and cut out, the remaining part of each image was saved and used for measurement of area fraction based on density of stained tissue using Northern Eclipse software (Empix Imaging Inc., Mississauga, ON, Canada). Islets were categorized as small $\left(300-2000 \mu \mathrm{m}^{2}\right)$, medium $\left(2000-10000 \mu \mathrm{m}^{2}\right)$ and large $\left(>10000 \mu \mathrm{m}^{2}\right)$. Very large islets $\left(>50000 \mu \mathrm{m}^{2}\right)$ were analyzed only in animals aged 45 days. Islets were traced manually and islet area was measured and expressed as a fraction of total section area. To evaluate islet size distribution, islet areas were pooled for each age group (14 days: $n=8$ per group; 23 and 30 days: $n=7$ per group; and 45 days: $n=5$ per group). Histograms of islet size distribution were generated using IgorPro (WaveMetrics, Portland, OR, USA) for small and medium islets and Prism 4 (GraphPad, San Diego, CA, USA) for large islets. Insulin ${ }^{+}$area was measured by manual tracing of one insulin-stained section from each animal, and area fraction was calculated by dividing stained area by section area. $\beta$-Cell mass and volume were calculated by multiplying insulin ${ }^{+}$area fraction by pancreas weight or volume, respectively, as described previously. ${ }^{21}$ EICs were counted manually at $\times 400$ and expressed as the number of EIC per $\mathrm{cm}^{2}$ tissue area.

\section{$\beta$-Cell Proliferation}

$\beta$-Cell proliferation was evaluated as described previously; ${ }^{2}$ and expressed as the percentage of $\mathrm{BrdU}^{+} /$insulin $^{+}$islet cells per total number of insulin ${ }^{+}$islet cells. EIC proliferation index was expressed as the percentage of $\mathrm{BrdU}^{+}$EIC cells per total number of EIC cells.

\section{Cell Cycle Distribution}

Tissue sections were stained for proliferating cell nuclear antigen (PCNA) (brown), and counterstained with Gill's modified hematoxylin (blue). The number of medium islet 
cells (583-1840 cells per section) in each phase of the cell cycle was analyzed at $\times 400$ essentially as described previously in hepatocytes. ${ }^{22-26} \mathrm{G} 0$, absence of nuclear or cytoplasmic staining; G1, patchy to uniform light brown nuclear staining without cytoplasmic staining; $\mathrm{S}$, strong and uniform dark-brown nuclear staining without cytoplasmic staining; and G2, dark-brown nuclear staining and diffuse, brown cytoplasmic staining. This analysis relies on patterns of nuclear and cytosolic PCNA staining. Therefore, double staining with PCNA and insulin to specifically identify $\beta$-cells would make it impossible to distinguish cells in G2. Thus, staining with PCNA alone was used and this analysis would also include a small number of non- $\beta$-cells. Data are expressed as the percentage of cells in each phase per total islet cells counted.

\section{Apoptosis}

Apoptosis was evaluated using morphological features of cells in hematoxylin and eosin (H\&E)-stained tissue sections. ${ }^{21}$ Apoptosis was also evaluated using transferase-mediated dUTP nick end labeling (TUNEL) with an in situ Cell Death Detection kit (Boehringer Mannheim, Mannheim, Germany).

\section{Laser Capture Microdissection}

LCM enables isolation of an enriched population of specific cells from tissue sections. To avoid RNA degradation during staining, frozen unstained tissue sections were sampled using a 'sandwich' approach as demonstrated in Figure 4a, panels 1-5. Serial cryostat sections of $5 \mu \mathrm{m}$ from pancreata were adhered to pre-cleaned slides and fixed with acetone at $4^{\circ} \mathrm{C}$. Every second tissue section was incubated with guinea-pig anti-insulin antibody and donkey anti-guinea-pig rhodamine red-conjugated antibody and then dehydrated with ethanol and xylene (Merck, Gibbstown, NJ, USA). The unstained middle sections were only fixed and dehydrated. Using the location of EIC on two consecutive slides stained for insulin, EIC were identified on the adjacent, middle unstained slides and collected using a PixCell II LCM system (Molecular Devices, Sunnyvale, CA, USA). Approximately 20 EIC were collected per animal for a total of 60-75 cells. Similarly, 60-75 cells from the core of islets were captured on separate LCM caps as demonstrated in Figure 4a, panels 6-8. Total RNA was extracted using a PicoPure kit (Molecular Devices) and contaminating DNA was removed using DNase treatment (DNase I, RNase-free; Roche Biochemicals, Mississauga, ON, Canada).

\section{Islet Isolation}

Islets were isolated from rat pancreata using a collagenase digestion protocol (collagenase Type XI, Sigma-Aldrich). ${ }^{27}$

\section{Gene Expression}

RNA was isolated using an RNeasy Mini kit (QIAGEN). Candidate genes of interest were analyzed using reverse transcriptase (RT)-PCR which was performed with Invitrogen reagents; primers were optimized separately for islet and LCM samples. Primers used for Neurogenin-3 (Ngn3) were $5^{\prime}$ (forward)-TGGCGCCTCATCCCTTGGATG and 3'(reverse)CAGTCACCCACTTCTGCTTCG; ${ }^{28}$ for pancreatic-duodenal homeobox gene 1 (Pdx1): 5' (forward)- CTCGCTGGGAACG CTGGAACA and $3^{\prime}$ (reverse)- GCTTTGGTGGATTTCATCC ACGG. ${ }^{29}$ For CyclinD2, cyclin-dependent kinase inhibitor 1a (Cdknla) and nerve growth factor- $\beta$ (Ngfb), primers were designed using the Clone Manager Suite from Scientific and Education Software (Cary, NC, USA). Cdknla: 5'(forward)TACGTCTGGGAGCGTGTTC and $3^{\prime}$ (reverse)-TCGGCGCT TGGAGTGATAG; CyclinD2: 5'(forward)-AGAGACCATCCC GCTGACTG and 3'(reverse)-GTCAACATCCCGCACGTCTG; Ngfb: $5^{\prime}$ (forward)-ACAGGGCAGACCCGCAACATCAC and $3^{\prime}$ (reverse)-TGCAGCCTTCCTGCTGAGCACAC.

Control studies showed that RT-PCR of mRNA from 50 to 160 LCM-isolated cells resulted in a linear response of PCR product. Gene expression was normalized to $\beta$-actin.

\section{Statistical Analysis}

The data in Figure 1 represent a single analysis of pooled samples from 5 to 8 rats and therefore no statistical analysis was performed. In Figures $2-6$, data are presented as mean \pm s.e.m. Differences between means were evaluated using Student's $t$-test or ANOVA followed by LSD post hoc analysis. Spearman's rank-order correlation analysis was performed to determine the relationship between age and Ngn3 expression (Figure $4 \mathrm{~d}$ and e). Linear regression analysis was used to evaluate the relation between BrdU index and islet size (Figure $5 \mathrm{c}$ and $\mathrm{d}$ ). Differences were considered statistically significant if $P<0.05$.

\section{RESULTS}

\section{Increased Number and Area Fraction of Small and Medium Islets but Reduced Number of Very Large Islets in BBdp Rats}

We analyzed small and medium islet area distribution in samples pooled from 5 to 8 animals per group in control and diabetes-prone animals aged 14, 23, 30 and 45 days (Figure la and b). The number of small islets was greater in BBdp compared with $\mathrm{BBc}$ rats. At 14 days, BBdp rat pancreata contained fewer large islets in the range of 20 000-30000 $\mu \mathrm{m}^{2}$ and this difference diminished with the increasing age (Figure 1c). Very large islets $\left(>50000 \mu \mathrm{m}^{2}\right)$ appeared at 45 days in both BBC and BBdp rats (Figure 1d). The contribution of these very large islets to total islet area was smaller in BBdp rats compared with $\mathrm{BBc}$ rats, 4.2 vs $15.2 \%$ of total islet area, respectively (Figure 1e).

We compared area fraction of small, medium and large islets at different ages (Figure 2). Area fraction of small and medium islets was greater in BBdp rats at young ages, 14-30 and 14-23 days, respectively. The area fraction of large islets was smaller in BBdp rats at 14 days, but remained essentially the same between 23 and 45 days. This resulted in similar 


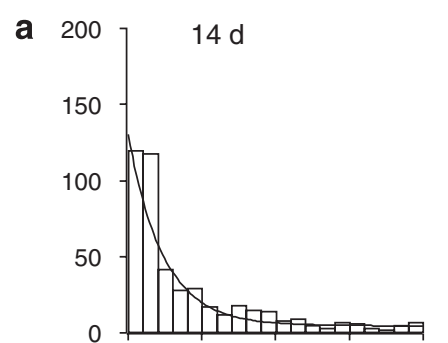

b
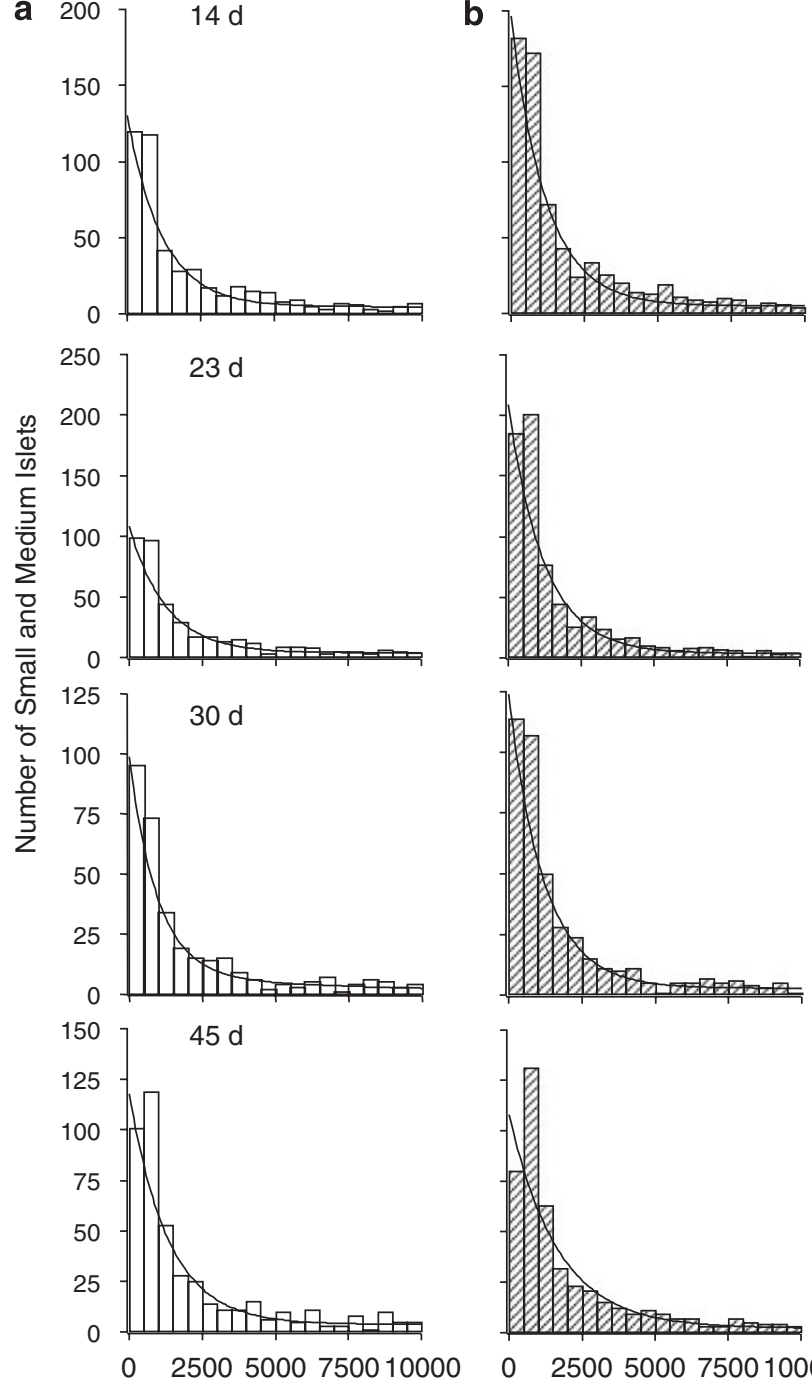

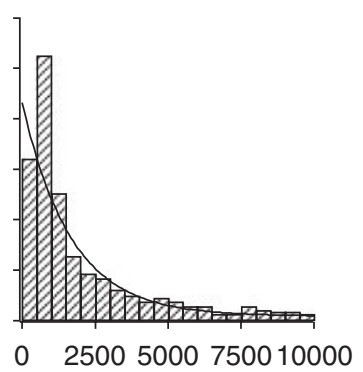

Islet Size $\left(\mu \mathrm{m}^{2}\right)$

d

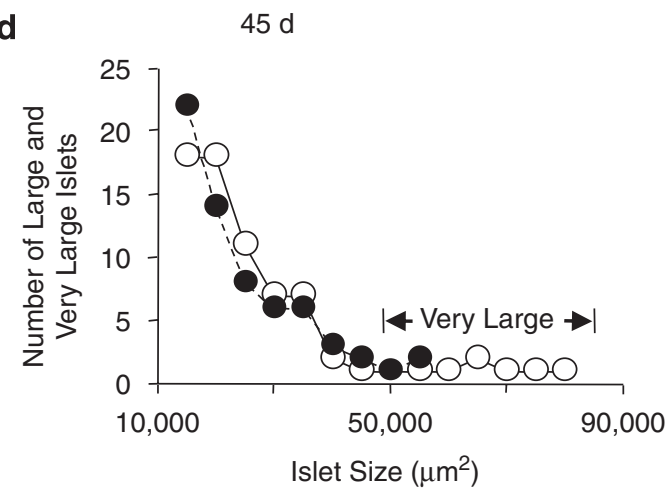

C
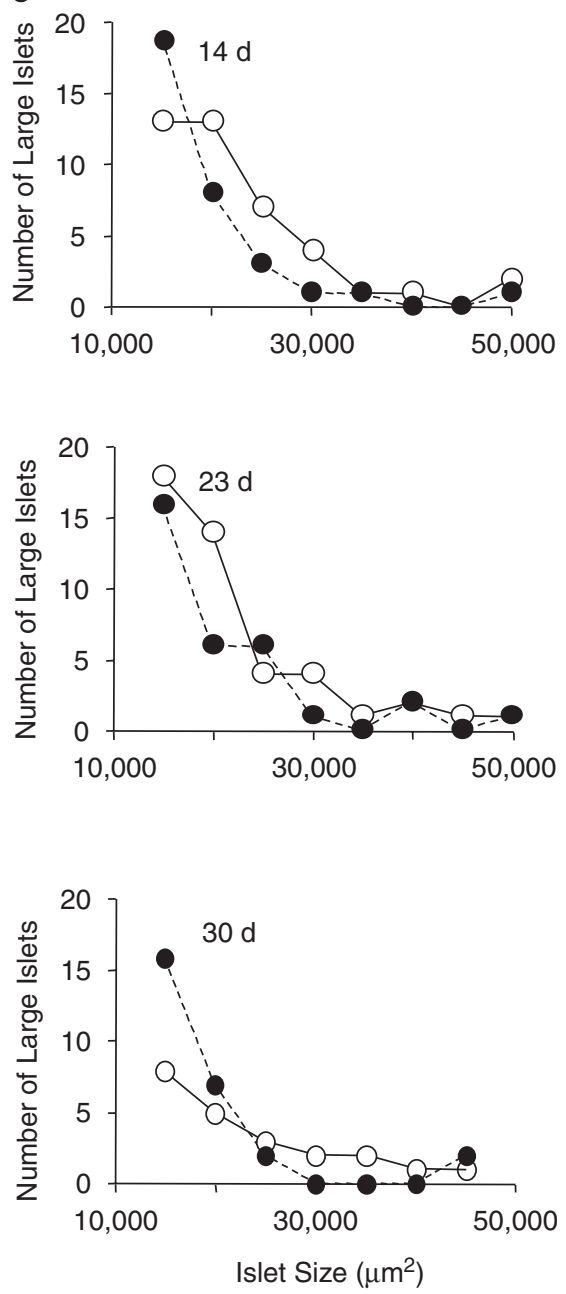

e

$45 \mathrm{~d}$

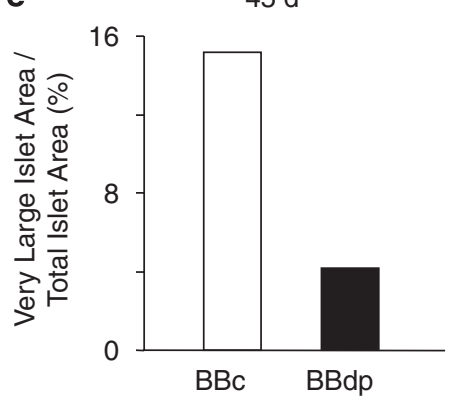

Figure 1 Size distribution of islets in pooled samples from young BioBreeding control (BBC) and BioBreeding diabetes-prone (BBdp) rats. Separate histograms were plotted based on pooled samples of eight animals per group at 14 days, seven per group at 23 and 30 days, five per group at 45 days. Size distribution of small and medium islets (300-10000 $\mu \mathrm{m}^{2}$ ) for BBc rats is shown in (a) (open bars), and for BBdp rats in (b) (hatched bars). Size distribution of large islets $\left(>10000 \mu \mathrm{m}^{2}\right)$ at 14,23 and 30 days is shown in (c) BBC, open circles and BBdp, filled circles. Size distribution of large and very large islets in pancreas of 45-day-old rats is shown in (d). The area fraction of very large islets $\left(>50000 \mu \mathrm{m}^{2}\right)$ is shown in (e). 

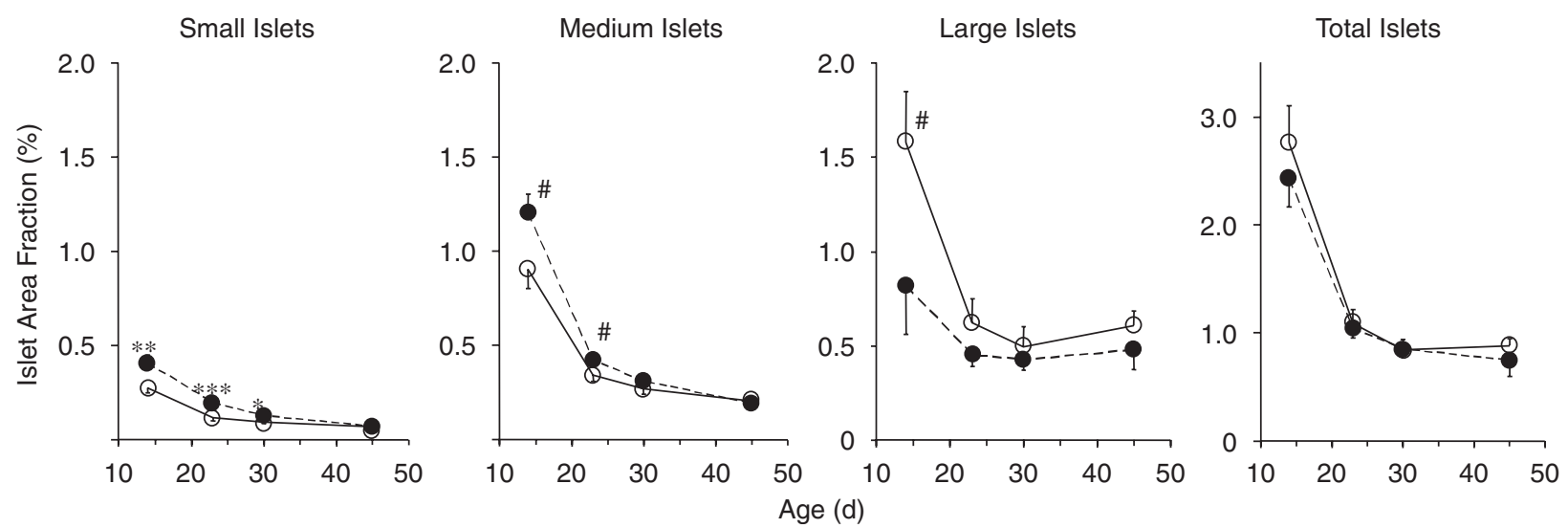

Figure 2 Islet area fraction in pancreata of BBC and BBdp rats aged 14-45 days. The area fraction of small (300-2000 $\left.\mu \mathrm{m}^{2}\right)$, medium (2000-10 000 $\left.\mu \mathrm{m}^{2}\right)$, large $\left(>10000 \mu \mathrm{m}^{2}\right)$ and total islets is shown. $\left({ }^{*} P<0.02 ;{ }^{*} P<0.01 ;{ }^{* *} P<0.0001 ;{ }^{*} P<0.05\right.$ compared with BBc. $n=5-8$ per group). $\bigcirc \mathrm{BBC}, \bullet \mathrm{BBdp}$.
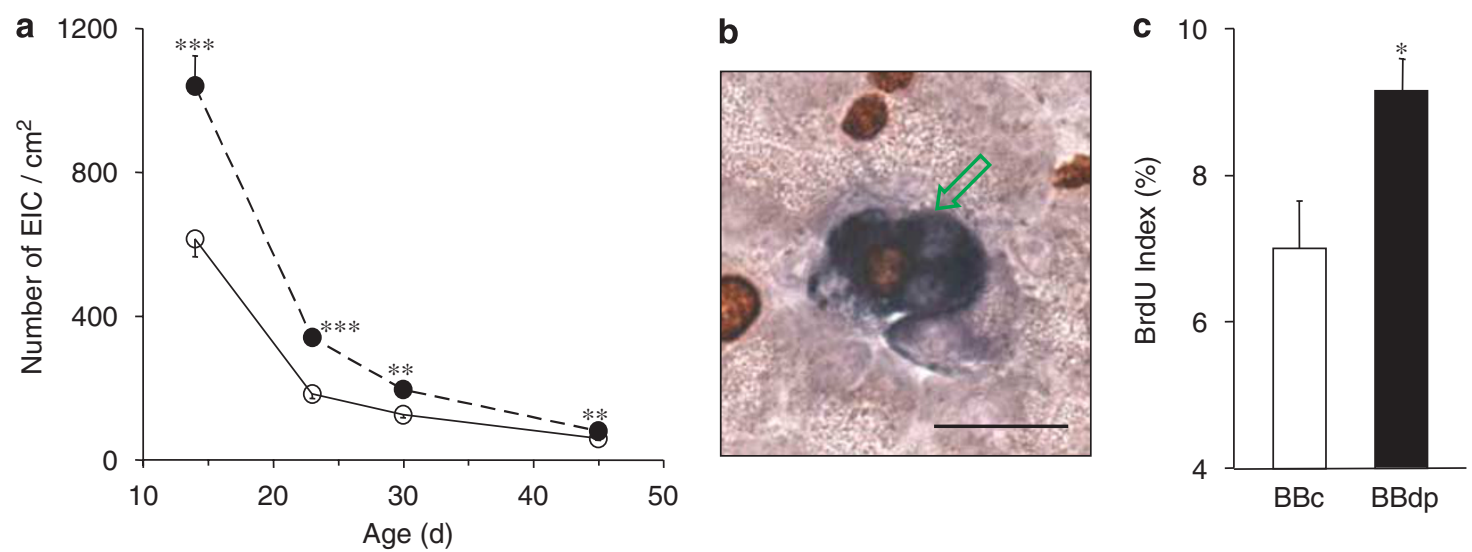

Figure 3 Number and proliferation of extra-islet insulin ${ }^{+}$clusters (EIC) in BB rat pancreas. (a) EIC number was higher in BBdp rats at all ages. Note: data at 45 days ( $59 \pm 4$ vs $79 \pm 3 / \mathrm{cm}^{2}$ tissue area, $P<0.002$ ) appear to be similar due to large scale of the $y$ axis. (b) Pancreas section showing insulin ${ }^{+}$(blue)/ 5-bromo-2-deoxyuridine ( $\mathrm{BrdU}^{+}$) (brown) EIC (green arrow), bar $=20 \mu \mathrm{m}$ and (c) percentage of $\mathrm{BrdU}^{+}$ElC was greater in $\mathrm{BBdp}$ vs $\mathrm{BBC}$ rats at 30 days. $\left({ }^{\star} P=0.01 ;{ }^{*} P<0.002 ;{ }^{* *} P<0.0003\right.$ compared with $\mathrm{BBC} ; n=5-8$ per group). (a) $\bigcirc \mathrm{BBC}$, $\bullet \mathrm{BBdp}$. (c) $\square \mathrm{BBC}$, $\square \mathrm{BBdp}$.

total islet area fraction and islet mass in the $\mathrm{BBdp}$ and $\mathrm{BBc}$ rat strains. Analysis of the number of islets showed similar differences but the total number of islets was larger in BBdp pancreas between 10 and 30 days due to more small and medium islets, but not large islets (data not shown).

\section{Similar $\beta$-Cell Mass in BBdp and BBC Rats}

Given the presence of increased small and medium islets, we expected to observe increased $\beta$-cell mass in BBdp rats. However, as with total islet area, no difference in total $\beta$-cell mass was observed. In BBdp and BBc rats, islet mass was $1.79 \pm 0.18$ vs $1.52 \pm 0.27 \mathrm{mg}(n=7$ per group, $P=0.4)$ at 30 days and $2.64 \pm 0.21$ vs $2.50 \pm 0.20 \mathrm{mg},(n=8$ per group, $P=0.6)$ at 45 days, respectively. The total $\beta$-cell volume at 45 days was $1.52 \pm 0.17$ vs $1.60 \pm 0.14 \mu \mathrm{l} \quad(n=8$ per group, $P=0.7)$ in $\mathrm{BBdp}$ and $\mathrm{BBc}$ rats, respectively. Because a previous study reported a lower $\beta$-cell mass in BBdp rats at 45 days, ${ }^{15}$ we analyzed $\beta$-cell mass in two additional experiments using a total of $21 \mathrm{BBdp}$ and $21 \mathrm{BBc}$ rats. In each experiment $\beta$-cell mass was similar. When data were combined, the $\beta$-cell mass of 45-day-old BBdp rats was $85.9 \pm 9.2 \%$ of controls $(P=0.2, n=21$ per group). Thus, despite enhanced production of small and medium islets in BBdp rats, total islet mass was similar or even smaller compared with $\mathrm{BBc}$ rats.

\section{Apoptosis in BB Rats}

To examine whether the impaired capacity to convert small and medium islets to larger islets was the result of increased apoptosis, the frequency of apoptotic cells was evaluated. Apoptotic bodies were rarely observed in either BBdp or BBc rat islets. At 14 days, no apoptotic bodies were 
a

Upper section - insulin

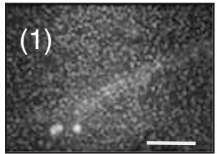

Middle unstained
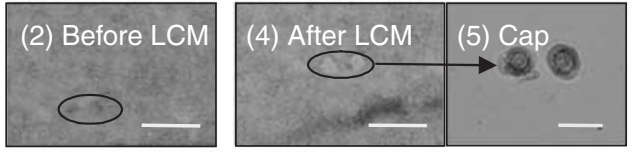

Lower section -insulin

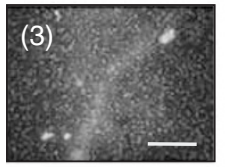

ISLETS
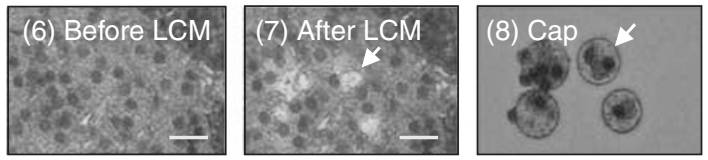

c
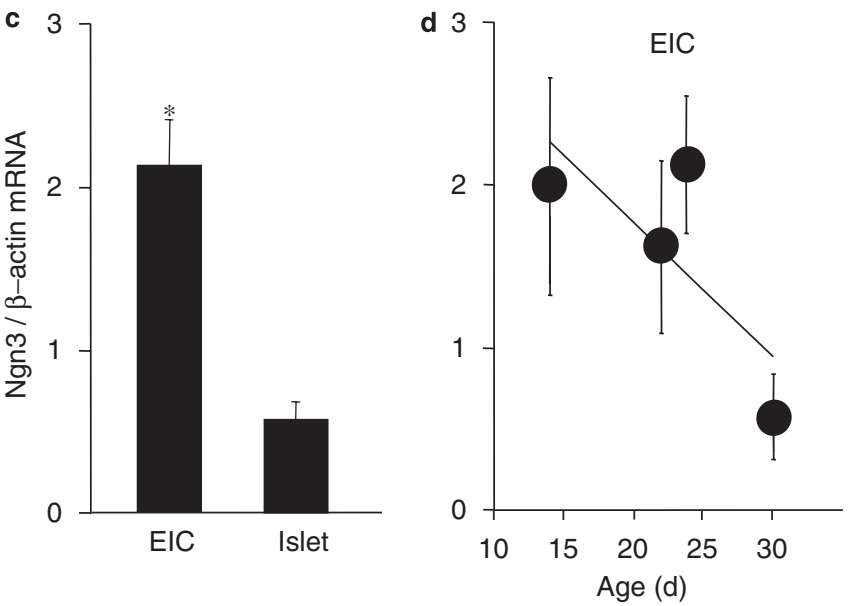

b
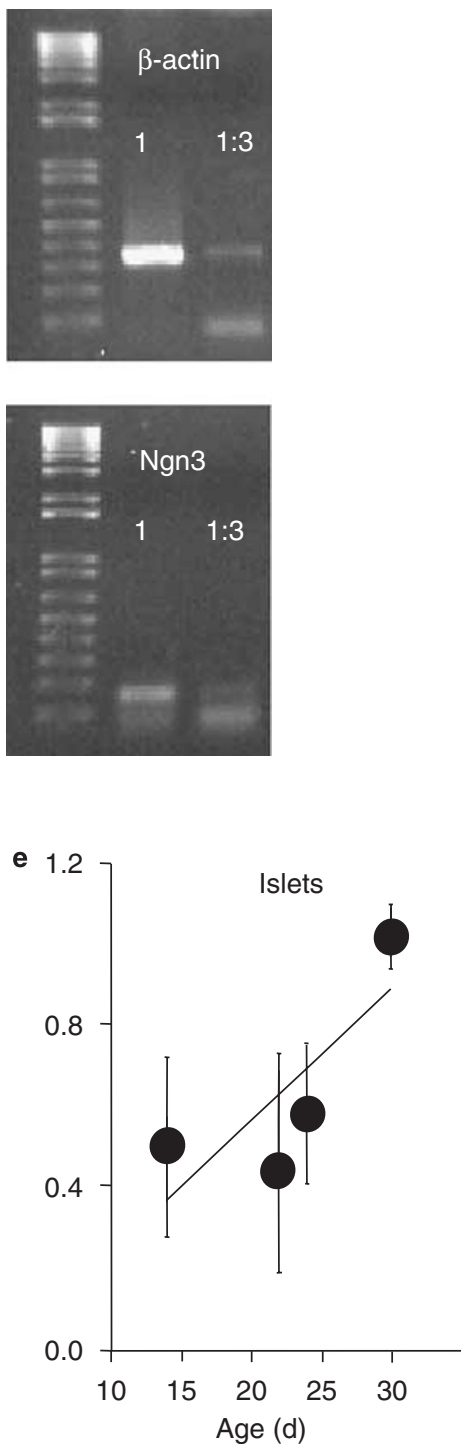

Figure 4 Neurogenin-3 (Ngn3) expression in BBdp rat extra-islet insulin ${ }^{+}$clusters (EIC) and islets isolated using laser capture microdissection (LCM). (a) Isolation of EIC from three adjacent sections using an LCM sandwich. At low magnifications, features on the tissue section, such as the ducts, can be used as landmarks to orient sections in the same position. At higher magnification, two fluorescent insulin ${ }^{+}$clusters were identified on stained sections (a1) and (a3): LCM was used to sample the middle unstained section (a2), tissue after removal of EIC (a4), EIC located on LCM cap (a5). LCM of core islet cells is shown in (a6-a 8). Bar $=160 \mu \mathrm{m}$ in (a)-a4); $80 \mu \mathrm{m}$ in (a5); $30 \mu \mathrm{m}$ in (a6) and (a7). (b)-(e) Ngn3 mRNA analyzed by reverse transcriptase (RT)-PCR in cells isolated using LCM. (b) RT-PCR showing a decrease in $\beta$-actin and Ngn3 expression when CDNA was diluted by 1:3 from a sample of isolated EIC. At 24 days, EIC from BBdp rats expressed higher Ngn3 levels compared with islet cells $(\mathbf{c})\left(n=9,{ }^{*} P<0.03\right)$. Ngn3 expression in ElC from BBdp rats decreased between 14 and 30 days ( $r=-0.46, P=0.04$, Spearman's correlation analysis) (d). In contrast, Ngn3 expression increased in islets of BBdp rats with increasing age from 14 to 30 days ( $r=0.48, P=0.03$, Spearman's correlation analysis), (e). (14 days, $n=4 ; 22$ days, $n=2 ; 24$ days, $n=9,30$ days, $n=5$ ).

observed in EICs or islets from H\&E-stained sections (BBc and BBdp, $n=8$ per group). Using TUNEL staining, an average of two apoptotic bodies per 100 islets was observed at 14 days, and only one apoptotic body per 100 islets was observed at 45 days. No apoptotic bodies were observed in EIC on either H\&E- or TUNEL-stained sections at 14 and 45 days. Thus, the frequency of apoptotic cells was low and did not differ between BBdp and BBc rat endocrine pancreas.

At 14 days, fewer apoptotic bodies were observed in TUNEL-stained acinar tissue of BBdp compared with BBc rats $\left(137 \pm 16\right.$ and $233 \pm 32$ per $\mathrm{cm}^{2}$ tissue area, respectively, $n=8$ per group, $P<0.02$ ). There was no evidence of mononuclear cell infiltration around EIC or islets between 14 
a
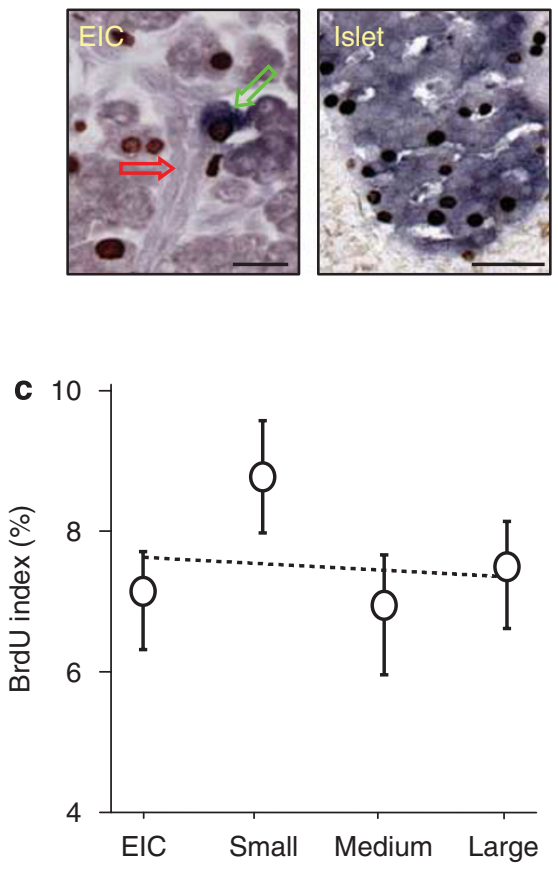

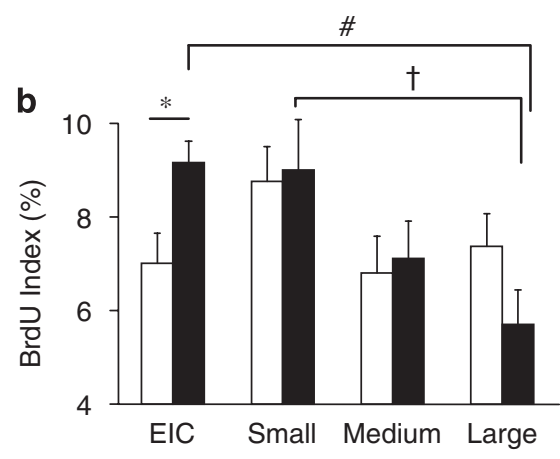

d 10

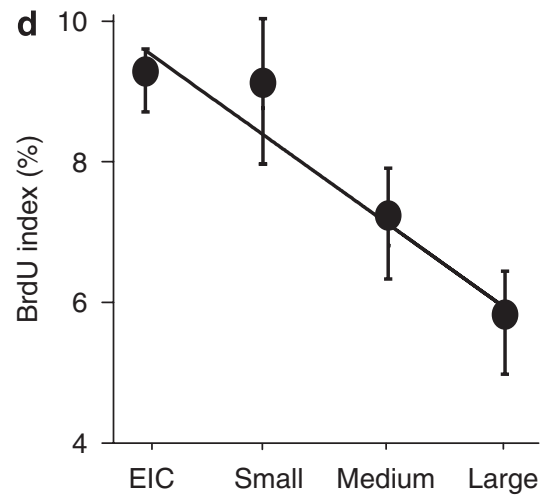

Figure 5 -Cell proliferation in BB rats. (a) Pancreas sections showing an insulin ${ }^{+}$(blue)/5-bromo-2-deoxyuridine (BrdU ${ }^{+}$) (dark-brown) extra-islet insulin ${ }^{+}$ cluster (EIC) (green arrow) budding from a ductule (red arrow), bar $=20 \mu \mathrm{m}$ and an islet stained for insulin (blue) and BrdU (dark-brown), bar $=40 \mu \mathrm{m}$. (b) Percentage of $\mathrm{BrdU}^{+}$/insulin ${ }^{+}$cells from 30-day-old rats. $n=7-8$ per group. Symbols represent differences obtained using ANOVA followed by LSD post hoc test, ${ }^{*} P=0.01 ;{ }^{\#} P=0.02 ;{ }^{\dagger} P=0.03$. Linear regression of BrdU index for EIC and islets in BioBreeding control (BBC) rats (c) and BioBreeding diabetesprone (BBdp) rats (d), which shows decreased $\beta$-cell proliferation with increasing islet size in $\mathrm{BBdp}$ rats only (linear regression: $\mathrm{BBC}, r=0.039, P=0.84$; $\mathrm{BBdp}$, $r=-0.60, P=0.0007)$. (b) $\square \mathrm{BBC}$, $\square \mathrm{BBdp}$. (c) $\bigcirc \mathrm{BBC}$. (d) $\bullet \mathrm{BBdp}$.

and 45 days, nor did we identify $\mathrm{CD} 3^{+}$cells accumulating around EIC or islets, confirming a lack of immune cell involvement at these ages (data not shown).

\section{Increased Number of Rapidly Proliferating EIC}

To determine the origin of the larger number of small islets in BBdp rats, we analyzed the number of EIC (Figure 3a) in pancreata of rats aged 14-45 days. Pancreata of BBdp rats contained more EIC compared with BBc rats. Cell proliferation of EIC was evaluated using BrdU incorporation (Figure 3b). BrdU was administered over a period of $72 \mathrm{~h}$ to allow sufficient time for labeling of putative stem/progenitor cells, which typically have low rates of replication. At 30 days, the fraction of $\mathrm{BrdU}^{+}$EIC was significantly larger in BBdp rats (Figure 3c), indicating increased proliferation. With few exceptions, only one insulin ${ }^{+}$cell per EIC was observed to contain $\mathrm{BrdU}$, demonstrating that the increased percentage of insulin ${ }^{+} / \mathrm{BrdU}^{+}$cells within EIC of BBdp rats was not from the daughter cells of dividing $\mathrm{BrdU}^{+}$EIC cells.

\section{Ngn3 Expression in EIC and Islets}

Ngn3 is a critical transcription factor directing endocrine cell formation during pancreatic development and is present in islet progenitors. $^{30}$ We analyzed Ngn3 expression using semiquantitative RT-PCR in LCM-isolated EIC and islet cells (Figure 4a and b). In 24-day-old BBdp rats, Ngn3 expression in EIC was higher than in islet cells (Figure 4c). In BBdp rats, Ngn3 expression in EIC decreased with age between 14 and 30 days (Figure $4 \mathrm{~d}, r=-0.46, P=0.04$ ). In contrast, Ngn3 mRNA levels in islets increased with increasing age in BBdp rats (Figure $4 \mathrm{e}, r=0.48, P=0.03$ ). In $\mathrm{BBc}$ rats, Ngn3 expression also increased with age in islets $(r=0.57, P=0.03)$, but this trend was not statistically significant for EIC (data not shown). To confirm Ngn3 expression patterns observed using LCM-isolated cells, whole islets were isolated using collagenase digestion from rats aged 30 days. Ngn3 expression was similar in islets isolated from BBdp and BBc rats (data not shown), consistent with results from the LCM sample analysis.

\section{Decreased Islet Cell Proliferation with Increased Islet Size}

To investigate why more EIC and small islets in BBdp rats did not correspond to an eventual increase in $\beta$-cell mass, we assessed $\beta$-cell proliferation using BrdU incorporation (Figure 5a). In 30-day-old BBdp rats, the proliferation indices of both EIC and small islets were significantly greater than those observed in large islets ( $P=0.02$ and 0.03 , respectively) (Figure $5 \mathrm{~b}$ ). However, only $2.8 \%$ of proliferating $\beta$-cells were 
a

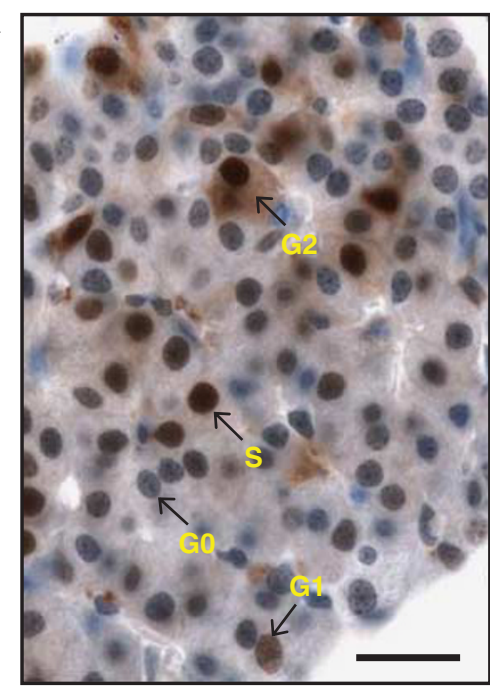

C

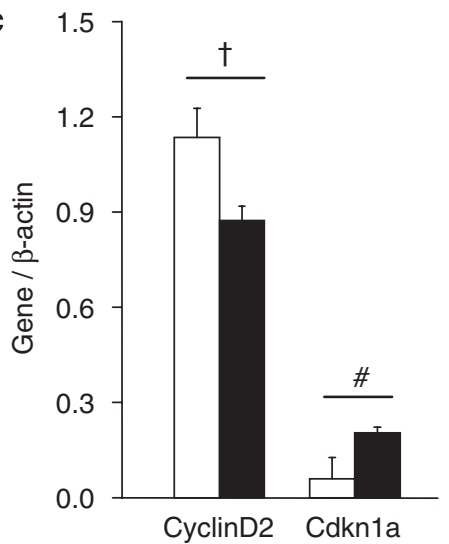

b
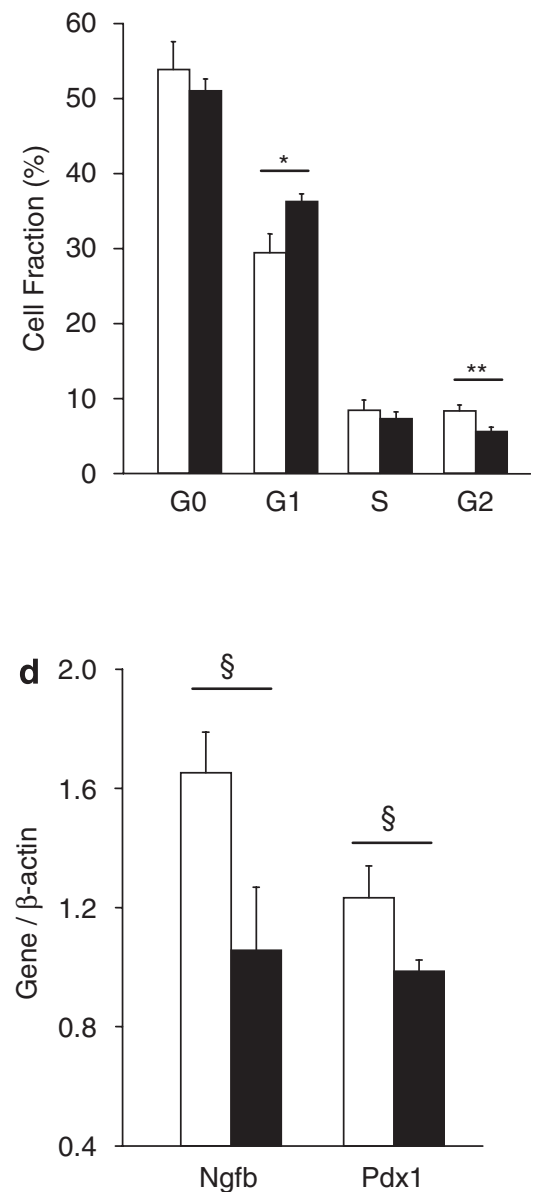

Figure 6 Islet cell cycle distribution and associated gene expression in 30 days BioBreeding (BB) rats. (a) Arrows indicate medium islet cells stained for proliferating cell nuclear antigen (PCNA) in G0, G1, S and G2 phase of the cell cycle, bar $=25 \mu \mathrm{m}$. (b) Distribution of islet cells in different cell cycle phases ( $n=7-8$ per group). (c) Expression of genes involved in cell cycle progression in isolated islets. (Student's $t$-test: ${ }^{*} P=0.02 ;{ }^{*} P=0.01 ;{ }^{\dagger} P<0.02$; ${ }^{\#} P<0.04$. $n=4-5$ per group). (d) Expression of developmental genes in islets. mRNA was extracted from medium-sized islets from 30-day-old rats and gene expression for nerve growth factor- $\beta$ ( $\mathrm{Ngfb}$ ) and pancreatic-duodenal homeobox gene 1 (Pdx1) was determined using reverse transcriptase (RT)-PCR (Student's t-test: ${ }^{\S} P<0.05, n=3-5$ per group). $\square$ BioBreeding control (BBC), $\mathbf{\square}$ BioBreeding diabetes-prone (BBdp).

in EIC, whereas $14.3,32.7$ and $50.1 \%$ of proliferating $\beta$-cells were found in small, medium and large islets, respectively. Therefore, the direct contribution of $\beta$-cell replication in EIC to total $\beta$-cell mass was small. In large islets, the proliferation index tended to be lower in BBdp compared with $\mathrm{BBC}$ rats $(P=0.10$, Figure $5 \mathrm{~b})$. Proliferation in $\mathrm{BBc}$ islets was not affected by islet size (Figure $5 c, P=0.84$ ). In contrast, when the mean proliferation index of BBdp islets was plotted against EIC and islet size (or islet size only), regression analysis revealed that islet cell proliferation was inversely correlated with islet size (Figure $5 \mathrm{~d}, P<0.001$ ). Acinar cell proliferation index was similar in BBdp and $\mathrm{BBC}$ rats $(3.0 \pm 0.5$ and $3.4 \pm 0.5 \%$, respectively, $n=3$ per group).

\section{A Partial Blockage in Cell Cycle of Islet Cells}

PCNA was stained and analyzed based on color of nuclei and staining pattern (Figure 6a) as described by others in hepato- cytes. ${ }^{22-26}$ At 14 days, we found no differences in islet cell cycle distribution between $\mathrm{BBdp}$ and $\mathrm{BBc}$ rats (data not shown). However, 1 week after weaning (30 days), subtle differences were observed in which the number of islet cells in G1 was increased and the number in G2 was slightly decreased in BBdp rats (Figure $6 \mathrm{~b} ; P=0.02$ and 0.01 , respectively), indicating a partial blockage in the cell cycle. This interpretation was further supported by analysis of mRNA levels of key regulatory cell cycle genes in 30 day islets isolated using collagenase digestion. We selected Cdknla, which induces G1 cell cycle arrest, ${ }^{31}$ as a candidate gene for analysis. RT-PCR analyses confirmed that the expression of Cdknla was increased in islets from BBdp compared with $\mathrm{BBC}$ rats (Figure 6c). The expression of cyclinD2, which is essential for cell cycle progression and $\beta$-cell replication, ${ }^{32}$ was lower in islets from BBdp rats (Figure $6 \mathrm{c}$ ), resulting in $\sim 4$-fold decrease in the ratio of cyclinD2/Cdkn1a. 


\section{Decreased Ngfb and Pdx1 Gene Expression}

We also analyzed expression of selected genes involved in islet development, maturation and morphogenesis. Ngfb promotes $\beta$-cell survival ${ }^{33,34}$ and increases islet morphogenesis. ${ }^{35}$ RT-PCR analysis revealed lower Ngfb expression in BBdp rats (Figure 6d), which could further contribute to the reduced capacity for $\beta$-cell survival and islet expansion. Pdx1 is an essential transcription factor in $\beta$-cell development, function, maintenance, regeneration, survival and insulin gene expression. ${ }^{36}$ BBdp islets also exhibited decreased Pdx1 expression (Figure 6d), further indicating a decreased capacity for islet expansion. NeuroD1, Pax4 and Pax6 were not different between rat types (data not shown). Thus, overall conditions were less favorable for islet expansion in pancreas of pre-insulitic diabetes-prone rats.

\section{DISCUSSION}

Knowledge of the natural course of islet $\beta$-cell development is limited, particularly in diabetes-prone individuals during the pre-insulitic period. Most studies of postnatal islet development have used some form of pancreas injury such as chemical treatment, surgery or transgenic expression of candidate molecules to amplify the normally low rate of $\beta$-cell turnover. In the present study, we examined the postnatal pancreas and identified several subtle abnormalities in the target tissue in young untreated BBdp rats.

We report an increase in the number of extra-islet insulin $^{+}$clusters, confirming our previous finding. ${ }^{2}$ This increase correlated with a higher number and area fraction of small and medium islets between 14 and 30 days with no difference in large islets between 24 and 45 days. In addition, there were fewer very large islets in 45-day-old BBdp rats (Figure $1 \mathrm{~d}$ and e). These data suggest a block in the development of larger mature islets in BBdp rats just before the period when immune cell infiltration becomes apparent. These results are consistent with early signs of $\beta$-cell hyperactivity $^{37,38}$ and increased number of small islets in NOD mice. ${ }^{13}$ Rosmalen et $a l^{38}$ pointed out that target tissue abnormalities may also be present before diabetes in human patients as reflected by aberrant proinsulin or C-peptide secretion. Thus, $\beta$-cell defects that precede the immune attack may not only attract self-reactive immune cells into the pancreas but could reduce the capacity to maintain a sufficient reservoir of islet $\beta$-cells to withstand a chronic immune attack.

EICs are thought to represent islet neogenesis, ${ }^{39}$ and possibly contain progenitor cells with the capacity to differentiate into functional endocrine cells. ${ }^{5}$ However, recent studies question the contribution of EICs in adults and their capacity to form islets in quantities sufficient to increase islet mass after injury. ${ }^{32,40-42}$ Here, we report that EIC are proliferating and retain Ngn3, a transcription factor critical for endocrine cell specification during pancreatic development. ${ }^{30}$ In 24-day-old BBdp rats, 1 day after weaning, Ngn3 mRNA levels in EICs were increased compared with islets, reinfor- cing the belief that EICs contain a sub-population of progenitors. With increasing age, Ngn3 expression decreased in EICs and increased in islets (Figure $4 \mathrm{~d}$ and e), demonstrating a shift from islet neogenesis at 24 days to mature intra-islet $\beta$-cell expansion at 30 days. These data support the view that, in post-weaning rodents, $\mathrm{Ngn}^{+}$cells in the pancreas are involved in the maintenance of $\beta$-cell mass. ${ }^{43}$ However, EIC cells represented only $2.8 \%$ of the total $\beta$-cell replication and therefore made a small contribution to total islet expansion. This suggests that cell proliferation from mature $\beta$-cells is the major driving force during the natural course of islet expansion in the pancreas of adult $\mathrm{BB}$ rats as reported recently in healthy adult mice. ${ }^{40-42}$ EICs have been documented in the human pancreas and comprise as much as $15 \%$ of total $\beta$-cell mass in adults, ${ }^{44}$ but it is not known whether a similar futile increase in islet neogenesis occurs in pre-diabetic humans.

$\beta$-Cell homeostasis is tightly controlled by a balance of cell proliferation and death. We observed very few apoptotic bodies in islets of 14 and 45 day rats (1-2 per 100 islets). This was similar to two reports: one in $\mathrm{BB}$ rats showed a low frequency of apoptotic bodies, less than $0.03 \%{ }^{15}$ and another in healthy older mice in which the rate of apoptosis was $0.001 \% .{ }^{45}$ Taking into account the increased $\beta$-cell proliferation and the low incidence of apoptosis observed in the present study, we expected the EIC in BBdp rats to progressively expand into islets. Indeed, we observed a higher frequency of small and medium islets in BBdp rats up to 30 days but without a concomitant increase in islet mass or volume, indicating a blockage in islet maturation. These data are consistent with a previous report of similar $\beta$-cell volume in 45 -day-old BBdp and BBc rats. ${ }^{46}$ In addition, a deficiency in $\beta$-cell development was noted in neonatal female NOD mice before the appearance of insulitis. ${ }^{47}$

The secretion of insulin in vitro is directly proportional to islet size. ${ }^{48}$ Large islets are major contributors to total islet mass and under normal conditions, they contribute disproportionately more to glucoregulation than smaller islets. ${ }^{6}$ There are also reports in other rat strains (Zucker lean and obese), that large islets are specifically decreased in animals subjected to protein malnutrition. ${ }^{49}$ A recent study also showed decreased area of large islets in offspring of Wistar rats fed a low-protein diet. ${ }^{50}$ Whether or not very large islets seen in $\mathrm{BBC}$ rats are a common feature of islet size distribution in humans remains unclear.

In BBdp rats, the number of very large islets was less at 45 days compared with $\mathrm{BBC}$ rats (Figure $1 \mathrm{~d}$ and e), further suggesting an inherent inability to expand $\beta$-cell mass through the formation of very large islets. This is consistent with the decreased amount of insulin in the blood and pancreas of young BBdp rats. ${ }^{51}$ An inability of small islets to further develop into medium- and large-sized islets has previously been described in young Sprague-Dawley rats following neonatal exposure to a high-carbohydrate diet. ${ }^{52}$ In 
addition, our preliminary data suggest that islet mass is modified by diet in BBdp rats. ${ }^{53}$

The data in control $\mathrm{BBc}$ rats are consistent with those observed in normal mice described by Teta $e t ~ a l^{54}$ in which all $\beta$-cells, regardless of islet size, were capable of proliferating at a similar rate. In contrast, the finding that $\beta$-cell proliferation in BBdp islets decreased with increasing islet size suggests a fundamental defect (Figure 5d). Thus, decreased proliferation and a lack of very large islets support the notion that $\beta$-cell expansion in pre-insulitic BBdp islets is compromised shortly after weaning. To investigate the basis of this defect, we determined the proportion of islet cells at different phases of the cell cycle at 30 days.

PCNA is an essential $33-\mathrm{kDa}$ protein implicated in the regulation of DNA replication, repair, chromatin remodeling and cell cycle control in mammals. ${ }^{55}$ Analysis of the pattern of PCNA staining in tissue sections, a well-accepted approach in studies of hepatocytes, ${ }^{22-25}$ enabled us to analyze different phases of the cell cycle without the confounding effects of acinar and duct cell contamination and also avoided the damage that is associated with islet cell isolation. This analysis revealed slightly more islet cells in the G1 phase and fewer cells in G2 in BBdp compared with BBc rats (Figure 6b), indicating a partial block in cell cycle progression. Because very few $\beta$-cells are capable of entering the active phase of the cell cycle ${ }^{56}$ it is expected that any blockage in islet cell cycle progression would negatively affect the already low capacity for $\beta$-cell renewal. There are few reports of $\beta$-cell cycle analysis in vivo. ${ }^{57}$ One study revealed a subtle block in the $\beta$-cell cycle in normal rats fed a low protein $\operatorname{diet}^{58}$ that was associated with an increase in G1 cells, delayed entry into $S$ phase, and reduced $\beta$-cell mass throughout life.

Cell cycle progression is tightly controlled by regulated expression of checkpoint genes ${ }^{56,57}$ including regulatory cyclins and their catalytic kinase subunits, the cyclin-dependent kinases (CDKs). Cyclin/CDK and PCNA form a quaternary complex which regulates cell cycle progression. ${ }^{59}$ CyclinD2, the dominant D-type cyclin in adult islets, ${ }^{45}$ is an essential $\beta$-cell replication factor implicated in triggering $\beta$-cell entry into the cell cycle ${ }^{60,61}$ and regulating $\beta$-cell mass. ${ }^{57}$ Cdknla inhibits CDKs, promoting G1 cell cycle arrest ${ }^{31}$ and blocking islet replication in response to growth factors. ${ }^{62}$ In this study, gene expression analysis revealed increased Cdkn1a and decreased cyclinD2 mRNA in islets of BBdp rats. The decrease in the ratio of cyclinD2 to Cdkn1a expression in BBdp islets would also favor G1 cell cycle arrest (Figure 6c). This interpretation is consistent with a study of cyclinD2 knockout mice in which marginal decreases in islet size and $\beta$-cell area at 3 months resulted in severe $\beta$-cell loss and glucose intolerance by 12 months. ${ }^{45}$ Expression of genes that support expansion of $\beta$-cells, $\mathrm{Ngfb}$ and Pdx1, was also lower in BBdp islets, suggesting additional unfavorable conditions for the maturation and survival of islets.

Small changes in neogenesis, replication, cell volume and apoptosis contribute to the modification of $\beta$-cell mass. ${ }^{3,45}$
These processes occur in a few cells at any given time and are difficult to measure. For example, islet neogenesis from various pathways is an infrequent event measured in terms of single cells ${ }^{39}$ and apoptosis in $\beta$-cells is rarely observed. To detect a difference in apoptosis between control and diabetesprone rats, O'Brien et al ${ }^{15}$ examined 15000 islet cells and calculated apoptosis incidences ranging from 0.02 to $0.14 \%$. Similarly, $\beta$-cell proliferation occurs at rates as low as 0.07 $2 \%$ per day. ${ }^{54,63}$ Thus, islet $\beta$-cell renewal occurs at very slow rates and any inhibition of islet maturation either through partial blockage of the cell cycle and/or decreased proliferation in mature islet cells would have a negative impact on the capacity of BBdp rats to maintain sufficient $\beta$-cell mass.

In conclusion, we describe a futile increase of islet neogenesis in the endocrine pancreas of young diabetes-prone animals before islet inflammation appears. This study reveals a weakened capacity to develop larger islets associated with a partial block in islet cell cycle, no change in apoptosis, decreased capacity for proliferation as the islets expand, a decreased ratio of cyclinD2/Cdkn1a genes and lower expression of key genes involved in islet development. Taken together, these conditions could limit the capacity to maintain islet mass above a critical threshold required for normoglycemia in the face of an immune attack.

\section{ACKNOWLEDGEMENT}

We are grateful to Dr William Ross, Director, Biostatistics, Health Canada, for statistical consultation. We thank Dr Olga Pulido and Peter Smyth from the Pathology Section, HPFB, Health Canada; Heidi Gruber, Jennifer Crookshank and Peipei Zheng for technical assistance; Jocelyn Souligny and Dominique Patry for animal care. This study was supported by the Canadian Diabetes Association, Canadian Institutes of Health Research, Juvenile Diabetes Research Foundation International, Canada Foundation for Innovation, Ontario Research and Development Challenge Fund and Canadian Discovery-Canadian Cure (Ottawa).

1. Rood PP, Bottino R, Balamurugan AN, et al. Facilitating physiologic selfregeneration: a step beyond islet cell replacement. Pharm Res 2006;23:227-242.

2. Wang GS, Karamchandani J, Pulido O, et al. Altered islet homeostasis before classic insulitis in BB rats. Diabetes Metab 2002;28:3590-3597; discussion 3S108-3S112.

3. Bonner-Weir S. Beta-cell turnover: its assessment and implications. Diabetes 2001;50(Suppl 1):S20-S24.

4. Teitelman G, Lee JK. Cell lineage analysis of pancreatic islet development: glucagon and insulin cells arise from catecholaminergic precursors present in the pancreatic duct. Dev Biol 1987;121:454-466.

5. Bouwens $L$, Rooman I. Regulation of pancreatic beta-cell mass. Physiol Rev 2005;85:1255-1270.

6. Skau M, Pakkenberg B, Buschard K, et al. Linear correlation between the total islet mass and the volume-weighted mean islet volume. Diabetes 2001;50:1763-1770.

7. Finegood DT, Scaglia L, Bonner-Weir S. Dynamics of beta-cell mass in the growing rat pancreas. Estimation with a simple mathematical model. Diabetes 1995;44:249-256.

8. Homo-Delarche F. Is pancreas development abnormal in the nonobese diabetic mouse, a spontaneous model of type I diabetes? Braz J Med Biol Res 2001;34:437-447.

9. Fernandes A, King LC, Guz Y, et al. Differentiation of new insulinproducing cells is induced by injury in adult pancreatic islets. Endocrinology 1997;138:1750-1762. 
10. Bonner-Weir S, Baxter LA, Schuppin GT, et al. A second pathway for regeneration of adult exocrine and endocrine pancreas. A possible recapitulation of embryonic development. Diabetes 1993;42:1715-1720.

11. Rosenberg L. Induction of islet cell neogenesis in the adult pancreas: the partial duct obstruction model. Microsc Res Tech 1998;43:337-346.

12. Wang RN, Kloppel G, Bouwens L. Duct- to islet-cell differentiation and islet growth in the pancreas of duct-ligated adult rats. Diabetologia 1995;38:1405-1411.

13. Pelegri C, Rosmalen JG, Durant $S$, et al. Islet endocrine-cell behavior from birth onward in mice with the nonobese diabetic genetic background. Mol Med 2001;7:311-319.

14. Trudeau JD, Dutz JP, Arany E, et al. Neonatal beta-cell apoptosis: a trigger for autoimmune diabetes? Diabetes 2000;49:1-7.

15. O'Brien BA, Fieldus WE, Field CJ, et al. Clearance of apoptotic beta-cells is reduced in neonatal autoimmune diabetes-prone rats. Cell Death Differ 2002;9:457-464.

16. Geutskens SB, Homo-Delarche F, Pleau JM, et al. Extracellular matrix distribution and islet morphology in the early postnatal pancreas: anomalies in the non-obese diabetic mouse. Cell Tissue Res 2004;318:579-589.

17. Strom A, Wang GS, Reimer R, et al. Pronounced cytosolic aggregation of cellular prion protein in pancreatic beta-cells in response to hyperglycemia. Lab Invest 2007;87:139-149.

18. Mordes JP, Bortell R, Blankenhorn EP, et al. Rat models of type 1 diabetes: genetics, environment, and autoimmunity. ILAR J 2004;45:278-291.

19. Palmer JP. Immunomodulatory therapy of human type 1 diabetes: lessons from the mouse. J Clin Invest 2001;108:31-33.

20. Wang GS, Rosenberg L, Scott FW. Tubular complexes as a source for islet neogenesis in the pancreas of diabetes-prone BB rats. Lab Invest 2005;85:675-688

21. Wang GS, Gruber $H$, Smyth P, et al. Hydrolysed casein diet protects BB rats from developing diabetes by promoting islet neogenesis. J Autoimmun 2000;15:407-416.

22. Rao PS, Mangipudy RS, Mehendale HM. Tissue injury and repair as parallel and opposing responses to $\mathrm{CCl} 4$ hepatotoxicity: a novel doseresponse. Toxicology 1997;118:181-193.

23. Kim HT, Stoica G, Bazer FW, et al. Interferon tau-induced hepatocyte apoptosis in sheep. Hepatology 2000;31:1275-1284.

24. Foley J, Ton T, Maronpot R, et al. Comparison of proliferating cell nuclear antigen to tritiated thymidine as a marker of proliferating hepatocytes in rats. Environ Health Perspect 1993;101(Suppl 5): 199-205.

25. Eldrige SR, Butterworth BE, Goldsworthy TL. Proliferating cell nuclear antigen: a marker for hepatocellular proliferation in rodents. Environ Health Perspect 1993;101(Suppl 5):211-218.

26. Celis JE, Celis A. Cell cycle-dependent variations in the distribution of the nuclear protein cyclin proliferating cell nuclear antigen in cultured cells: subdivision of S phase. Proc Natl Acad Sci USA 1985;82:3262-3266.

27. Huang L, Shen $H$, Atkinson MA, et al. Detection of exocytosis at individual pancreatic beta cells by amperometry at a chemically modified microelectrode. Proc Natl Acad Sci USA 1995;92:9608-9612.

28. Jensen J, Heller RS, Funder-Nielsen T, et al. Independent development of pancreatic alpha- and beta-cells from Neurogenin3-expressing precursors: a role for the Notch pathway in repression of premature differentiation. Diabetes 2000;49:163-176.

29. Jensen J, Serup P, Karlsen C, et al. mRNA profiling of rat islet tumors reveals nkx 6.1 as a beta-cell-specific homeodomain transcription factor. J Biol Chem 1996;271:18749-18758.

30. Apelqvist A, Li H, Sommer $\mathrm{L}$, et al. Notch signalling controls pancreatic cell differentiation. Nature 1999;400:877-881.

31. Harper JW, Adami GR, Wei N, et al. The p21 Cdk-interacting protein Cip1 is a potent inhibitor of G1 cyclin-dependent kinases. Cell 1993:75:805-816.

32. Georgia S, Bhushan A. Beta cell replication is the primary mechanism for maintaining postnatal beta cell mass. J Clin Invest 2004;114:963-968.

33. Reimer MK, Mokshagundam SP, Wyler K, et al. Local growth factors are beneficial for the autonomic reinnervation of transplanted islets in rats. Pancreas 2003;26:392-397.

34. Miao G, Mace J, Kirby $\mathrm{M}$, et al. In vitro and in vivo improvement of islet survival following treatment with nerve growth factor. Transplantation 2006;81:519-524.
35. Kanaka-Gantenbein C, Dicou E, Czernichow P, et al. Presence of nerve growth factor and its receptors in an in vitro model of islet cell development: implication in normal islet morphogenesis. Endocrinology 1995;136:3154-3162.

36. Johnson JD, Ahmed NT, Luciani DS, et al. Increased islet apoptosis in Pdx1+/- mice. J Clin Invest 2003;111:1147-1160.

37. Sreenan S, Pick AJ, Levisetti $M$, et al. Increased beta-cell proliferation and reduced mass before diabetes onset in the nonobese diabetic mouse. Diabetes 1999;48:989-996.

38. Rosmalen JG, Leenen PJ, Pelegri $C$, et al. Islet abnormalities in the pathogenesis of autoimmune diabetes. Trends Endocrinol Metab 2002;13:209-214.

39. Lipsett M, Aikin R, Castellarin M, et al. Islet neogenesis: a potential therapeutic tool in type 1 diabetes. Int J Biochem Cell Biol 2006;38:498-503.

40. Dor $\mathrm{Y}$, Brown J, Martinez $\mathrm{Ol}$, et al. Adult pancreatic beta-cells are formed by self-duplication rather than stem-cell differentiation. Nature 2004;429:41-46.

41. Teta M, Rankin MM, Long SY, et al. Growth and regeneration of adult beta cells does not involve specialized progenitors. Dev Cell 2007;12:817-826.

42. Brennand $K$, Huangfu $D$, Melton $D$. All beta cells contribute equally to islet growth and maintenance. PLoS Biol 2007;5:e163.

43. Gu G, Dubauskaite J, Melton DA. Direct evidence for the pancreatic lineage: NGN3+ cells are islet progenitors and are distinct from duct progenitors. Development 2002;129:2447-2457.

44. Bouwens L, Pipeleers DG. Extra-insular beta cells associated with ductules are frequent in adult human pancreas. Diabetologia 1998:41:629-633.

45. Kushner JA, Ciemerych MA, Sicinska E, et al. Cyclins D2 and D1 are essential for postnatal pancreatic beta-cell growth. Mol Cell Biol 2005;25:3752-3762.

46. Lohr $M$, Markholst $H$, Dyrberg $T$, et al. Insulitis and diabetes are preceded by a decrease in beta cell volume in diabetes-prone BB rats. Pancreas 1989:4:95-100.

47. Hill DJ, Arany EJ. Altered pancreatic development in the neonatal NOD mouse precedes autoimmune diabetes. Proceedings 82nd Annual Meeting of the Endocrine Society 2000. The Endocrine Society: Toronto, Abstract 285.

48. Reaven EP, Gold G, Walker W, et al. Effect of variations in islet size and shape on glucose-stimulated insulin secretion. Horm Metab Res 1981;13:673-674.

49. Tse EO, Gregoire FM, Reusens B, et al. Changes of islet size and islet size distribution resulting from protein-malnutrition in lean $(\mathrm{Fa} / \mathrm{Fa})$ and obese (fa/fa) Zucker rats. Obes Res 1997;5:563-571.

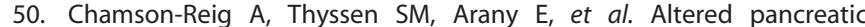
morphology in the offspring of pregnant rats given reduced dietary protein is time and gender specific. J Endocrinol 2006;191:83-92.

51. Scott FW, Olivares E, Sener A, et al. Dietary effects on insulin and nutrient metabolism in mesenteric lymph node cells, splenocytes, and pancreatic islets of BB rats. Metabolism 2000;49:1111-1117.

52. Petrik J, Srinivasan $M$, Aalinkeel $R$, et al. A long-term high-carbohydrate diet causes an altered ontogeny of pancreatic islets of Langerhans in the neonatal rat. Pediatr Res 2001;49:84-92.

53. Wang GS, Kauri LM, Patrick C, et al. Enhanced islet neogenesis and beta-cell proliferation in pre-insulitic diabetes-prone rats fed a hydrolyzed casein diet. FASEB $J$ 2007;21:A771.

54. Teta M, Long SY, Wartschow LM, et al. Very slow turnover of \{beta\}cells in aged adult mice. Diabetes 2005;54:2557-2567.

55. Naryzhny SN, Zhao H, Lee H. Proliferating cell nuclear antigen (PCNA) may function as a double homotrimer complex in the mammalian cell. J Biol Chem 2005;280:13888-13894.

56. Rane SG, Reddy EP. Cell cycle control of pancreatic beta cell proliferation. Front Biosci 2000;5:D1-D19.

57. Cozar-Castellano I, Fiaschi-Taesch N, Bigatel TA, et al. Molecular control of cell cycle progression in the pancreatic beta-cell. Endocr Rev 2006:27:356-370.

58. Petrik J, Reusens B, Arany E, et al. A low protein diet alters the balance of islet cell replication and apoptosis in the fetal and neonatal rat and is associated with a reduced pancreatic expression of insulin-like growth factor-II. Endocrinology 1999;140:4861-4873.

59. Kontopidis G, Wu SY, Zheleva DI, et al. Structural and biochemical studies of human proliferating cell nuclear antigen complexes provide 
a rationale for cyclin association and inhibitor design. Proc Natl Acad Sci USA 2005;102:1871-1876.

60. Kushner JA. Beta-cell growth: an unusual paradigm of organogenesis that is cyclin D2/Cdk4 dependent. Cell Cycle 2006;5: 234-237.

61. Fatrai S, Elghazi L, Balcazar N, et al. Akt induces beta-cell proliferation by regulating cyclin D1, cyclin D2, and p21 levels and cyclindependent kinase-4 activity. Diabetes 2006;55:318-325.
62. Cozar-Castellano I, Weinstock $M$, Haught $M$, et al. Evaluation of betacell replication in mice transgenic for hepatocyte growth factor and placental lactogen: comprehensive characterization of the G1/S regulatory proteins reveals unique involvement of p21cip. Diabetes 2006;55:70-77.

63. Weir GC, Laybutt DR, Kaneto $\mathrm{H}$, et al. Beta-cell adaptation and decompensation during the progression of diabetes. Diabetes 2001;50(Suppl 1):S154-S159. 